The Geneva Papers on Risk and Insurance, 21 (No. 81, October 1996), 557-575

\title{
End of Occupational Life and Transition to Retirement: a Challenge for Swiss Institutions?
}

\author{
by Maryvonne Gognalons-Nicolet*, Xavier Gaullier** \\ and Anne Bardet Blochet*
}

Social organisation of the human life-cycle, and particularly its division into age groups, has undergone profound changes. To the three classic stages in the life-cycle - preparation for occupational life, remunerated activity and family life, and withdrawal from active life (retirement) - are now added periods of transition of increasing duration and whose shape is becoming increasingly difficult to predict:

- adolescence, and frequently post-adolescence, from the ages of 15 to 25 or even 30 years;

- maturescence (i.e. early to late middle-age), characterised by age-related events in work and family life and by health problems. ${ }^{1}$

The results of a transverse survey carried out in 1985 on a representative sample of the Geneva population aged between 40 and 65 years ( 405 men and 415 women) have made it possible to approach this period of "early to late middle-age" as a specific phase in the life-cycle, a "cross-roads" in the aging process, at which age-related changes begin to appear. ${ }^{2}$ One of the first purposes of this transverse survey was to define an historical context for the sample population by stressing in relation to work and the family those features which make this age category unique. A second objective was to examine the impact of occupational and family problems on declining health status.

*HUG Belle-Idée, Unité d'Investigation Clinique, Equipe psychosociale, Genève.

** CNRS, Paris.

1 Some of the results have already been published in various works, among which, "La Maturescence", P.M.Favre,1989 and "La Santé en Suisse", Payot, 1993.

${ }^{2}$ The first transverse survey was undertaken with a subsidy from the FNRS (request No 3972.082 ), and this was followed by initial and partial longitudinal results supported by a second request (No 3920.0-87). At present, thanks to a third subsidy (request No 32.33444-92), the entire sample population is under review. 
In 1993-94, a further survey was undertaken to gather information about the fate of the sample population and to examine the problems posed by cessation of occupational life and by the various modes of transition to retirement. The purpose of this paper, on the basis of initial results and of what was discussed at the scientific meeting held in Geneva in October $1994,{ }^{3}$ is to attempt to assess just how well-coordinated and different Swiss retirement arrangements really are by comparison with other industrial societies, especially European ones. In recent decades, for men, there has been a trend towards retirement around the age of 65 becoming standard practice. For women, it is only very recently that feminine cohorts with a relatively sustained occupational career behind them have been reaching retirement age. By identifying and scrutinizing in detail the various modes of exit from occupational life and of transition into retirement, as observed in the context of an economy in recession, we shall be able to decide how specific Swiss arrangements are and how they compare with what is being done in other industrial societies.

\section{Exits from occupational life and transitions to retirement: proliferation and diversity of social status}

The setting-up of the AVS in 1948 and subsequently of the 2nd Pillar (LPP, 1985), made possible by decades of economic prosperity, has made available to an aging population a long-awaited and much-desired period of rest free from occupational obligations. In Switzerland, as in most other industrialised societies (Lalive d'Epinay, 1987), this period is viewed as a new time of life, rich in family and community activities.

Swiss studies of the demographic and social context of the transition to retirement have been summarised in four major reports which are veritable mile-stones in the scientific recording of national knowledge and experience. Following publication of the Saxer Report in 1966, the report Vieillir en Suisse (which appeared in 1979) laid stress on problems specific to the aging process in light of the gerontological theories of the 60's and 70's. The progress report on research into aging in Switzerland (Hopflinger \& al., 1992) and, more recently, the Vieillir en Suisse Report of 1995 have used the earlier studies in highlighting the social design of retirement as part of a broader, more global approach, encompassing the entire life-cycle.

The economic crisis of the early 90's, which occurred a little later in Switzerland than in other industrialised societies, altered inter alia the modes of exit from occupational life and transition to retirement. By identifying those features which are specific to Swiss arrangements, and the new risks which for the time being have been studied above all in other European countries, it should prove possible to define a set of issues which will serve as a background to the subsequent scrutiny of survey results.

In comparison to the institutions of other countries, Switzerland is marked by compartmentalisation of its systems of social protection, each designed to cover a specific risk (old-age pensions, unemployment insurance, insurance for loss of earnings through acci-

${ }^{3}$ In light of the fresh longitudinal data, a scientific meeting was held in Geneva on 20 October 1994 (FNRS subsidy 3201.04603.94). It was attended by the directors of the various Genevan social insurance funds (AVS, AI and Unemployment) and its purpose was to compare initial longitudinal results from the survey with cantonal social-benefit statistics and with national and international statistics adduced by different experts (W.Weiss and X.Gaullier). 
dent, etc.), "each with its own bureaucracy, its own rules and regulations, its own systems of contribution and benefit disbursement, its own procedures, sanctions and criminal provisions, etc " (Sommer \& Hopflinger, 1990). The three-pillar system encourages provision of welfare in tiers (state, occupational and personal schemes) a fact that was officially recognised in a recent Federal Department of the Interior report which established such provision on a legal footing compatible with the legislation of other European countries. As Greber (1994) has stated, discussion about the overall coherence of the system has always been neglected in favour of a more pragmatic, short-termist approach (page 63).

The 1st Pillar (the AVS) which is run on contributive lines (according to the number of contribution years) and on a pay-as-you-go basis (according to the principle of transfer from the active to the inactive) is financed from income for remunerated work to which is added a $20 \%$ state contribution. The AVS is the only "social policy" which makes the benefits of wealth redistribution available to the entire population. Payment of the pension enters into force at ages stipulated by statute, at 62 and 65 years. The 2nd Pillar, made universal by the Basic Law (LPP) of 1985, takes the form of an individual occupational insurance by capitalisation whose shape varies from firm to firm and depends upon the date of entry by the employee concerned into the provident fund. This 2 nd Pillar occupational insurance does not depend upon generational transfer, but is a function of contributions made during occupational life. Even from this very brief description it can be seen that the efficacy of this type of scheme very much depends upon the duration and type of career pursued, masculine, continuous, full-time occupational patterns being favoured over the more typically feminine, intermittent and part-time career paths which take no account of household and family activities. In this regard, a recent work by Luchsinger (1995) lays very great stress on the role of women in the history of the AVS.

The institutional history of these two major retirement benefit schemes has already been amply described, while the overall coherence of the systems and their sociological context still need to be studied. Definitive cessation of remunerated activity at a given age does not always coincide with the drawing of a pension although over the last three decades there has been standardisation of the age at which the latter occurs (Lalive d'Epinay, 1987). Whether anticipated or deferred, retirement varies from one profession to the next, its shape also depending upon the number of 2 nd Pillar contribution years, the historical characteristics of the firm pension fund concerned, and on any plans for remunerated activity after retirement an employee may have. The option available to retirees to withdraw their accumulated pension as a lump sum makes the Swiss system rather special, confronting the individual with problems of choice which are further complicated by institutional constraints.

Recent changes on the labour market, however, have disturbed existing equilibria inherited from an industrial society dominated by a powerful work ethic. The wave of early retirement plans designed to tackle the problems of the greying age pyramid within firms has called into question the very definition of retirement. The closure of many firms, together with the increase in the incidence of long-term unemployment at end of career, make fresh approaches to labour-market exit, replacement incomes and a much-needed coordination of the various social insurance schemes unavoidable. Different social situations accompany each of the various available options from pre-retirement and/or early retirement before the 1st Pillar entitlement age to deferred retirement - the securing of a 
pension, partial or total cessation of occupational activity on reaching the offical pension age, or the extension of work. Dependent, as it is, on factors which have to do with position in the social strata, length of career and institutional considerations, the period between 55 and 65 years has become an important theatre of political and social negotiation in which the crisis affecting three areas - employment, social welfare and social identity are all reflected (Gaullier, 1994). This critical period in the life-cycle, described by Gaullier as "the decade of retirement", has become a touch-stone of the economic crisis, with grave implications for social solidarity in general (Eme, 1994).

As can be seen from Figure 1,61.6\% of the population can be described as "retired" since it has left the labour market for good and is drawing at least an AVS pension. $21.1 \%$ quitted before the statutory pension age to enjoy early retirement under 2nd Pillar schemes and $17.3 \%$ continue in an occupational activity while drawing a 1st Pillar pension.

Figure 1: Exits from occupational life, modes of transition to retirement and extension of occupational life - 10 years on

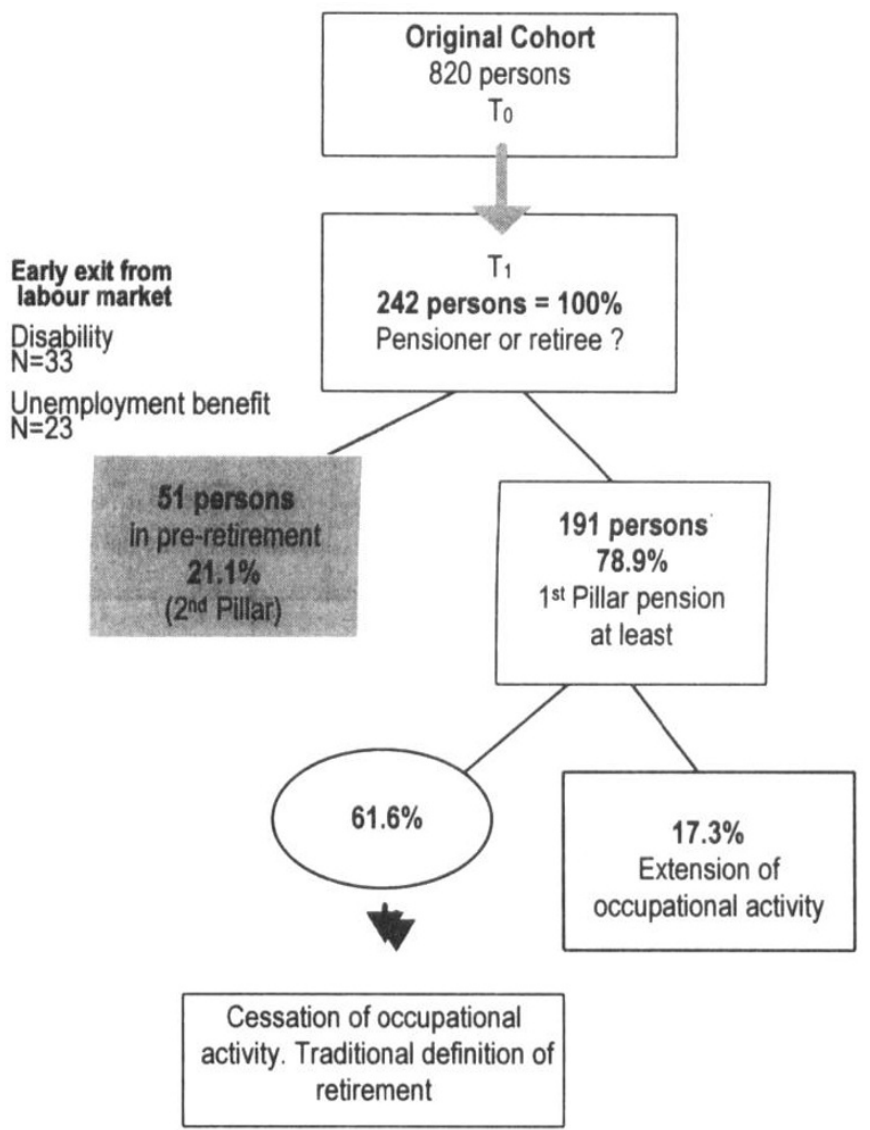


Two other situations are found to occasion early exit from occupational life: disability and unemployment. For the time being, we shall limit ourselves merely to stating the number involved and shall decide only at a later stage which fall into the "hidden" situations category or into categories not recognised by the social insurance schemes concerned.

Since the late 70's, following agreements among government, enterprises and unions, various pre-retirement schemes have been set up in a number of EU countries. In order to overcome the problem of overstaffing in firms and rising unemployment, older workers have been encouraged in various ways - compulsory redundancy, voluntarily or by negotiation - to bring forward their exit from occupational life (Drury, 1993). Negotiation nationally of public policy among the social partners has assumed the existence of two distinct but inter-related problem areas:

- employment, overstaffing in firms and end of career management;

- provision of social welfare and risk management with respect to unemployment, disability and old-age, and, behind them, the historical and cultural specifics of the retirement institutions themselves which vary from one country to the next.

The question we would wish to address as far as Switzerland is concerned is as follows: how is institutional provision for the management of pensions and retirement coping with the new risks posed by the employment crisis and by the incidence of long-term unemployment and disability among older workers of both genders?

Whether the individual has chosen to retire or has been forced to do so can be determined either from the replies of those concerned or from the nature of the institutions and their contributors, or again from the labour market. The results derive from a population survey and require a review of the entire system. What explanations for exit from occupational life were given and what transition paths into retirement were chosen? How do such explanations relate to each other or can they, on the contrary, be said to be independent? Alongside the arguments adduced by the retirees and/or the pensioners themselves, the occupational and economic characteristics of each group will make it possible to determine which social groups have benefitted from, and which have been jeopardised by, changes in modes of transition to retirement.

\section{Longitudinal follow-up 10 years on: what was involved in practice}

The results of a partial follow-up in 1989 (Gognalons-Nicolet \& al.,1991) revealed that the population refusing to re-establish contact frequently manifested the characteristics of risk of serious illness akin to those of the deceased population. As we have already had the occasion to emphasize, the drop-out portion (from 30 to $40 \%$ ) of the population impossible to relocate during longitudinal follow-ups constitutes a high-risk group. Moreover, if one wishes to study those features which are specific to this representative population aged between 40 and 65 years at $\mathrm{T}_{0}$, it is essential to relocate as many members of the original cohort as possible.

It was for this reason that, in conducting our field study, we adopted a double strategy which, for the population refusing to be interviewed at home, involved our making a 5minute telephone interview in order to obtain a maximum of information regarding the 
major events that had occurred since our first visit, especially in respect of end of occupational life and transition to retirement. This two-tier field strategy involved an initial telephone contact to arrange a home-visit for interview purposes and, should the latter be refused, a short telephone questionnaire lasting a few minutes was proposed to gather essential information. As Figure 2 shows, this approach proved fruitful since, with the exception of 6 persons whom we were unable to retrace and for whom as a result we have no new information, we are able to state that the data regarding end of occupational life and transition to retirement refers to the original cohort in its entirety. Stress should, we believe, be laid upon the field approach adopted in light of what is a universal research problem. For if it is true that longitudinal studies are essential to a proper understanding of the aging process, especially pathological aging, one should not at the same time underestimate the importance of drop-outs who constitute a heterogeneous group of individuals who are displaced, mobile, at times deceased and, as a result, impossible to retrace. Moreover, special attention was given to analysing the deceased population of 47 persons, $5.7 \%$, that is, of the original cohort.

\section{Figure 2: Field conditions for the longitudinal follow-up of a repre sentative population aged 40 to 65 years 10 years on}

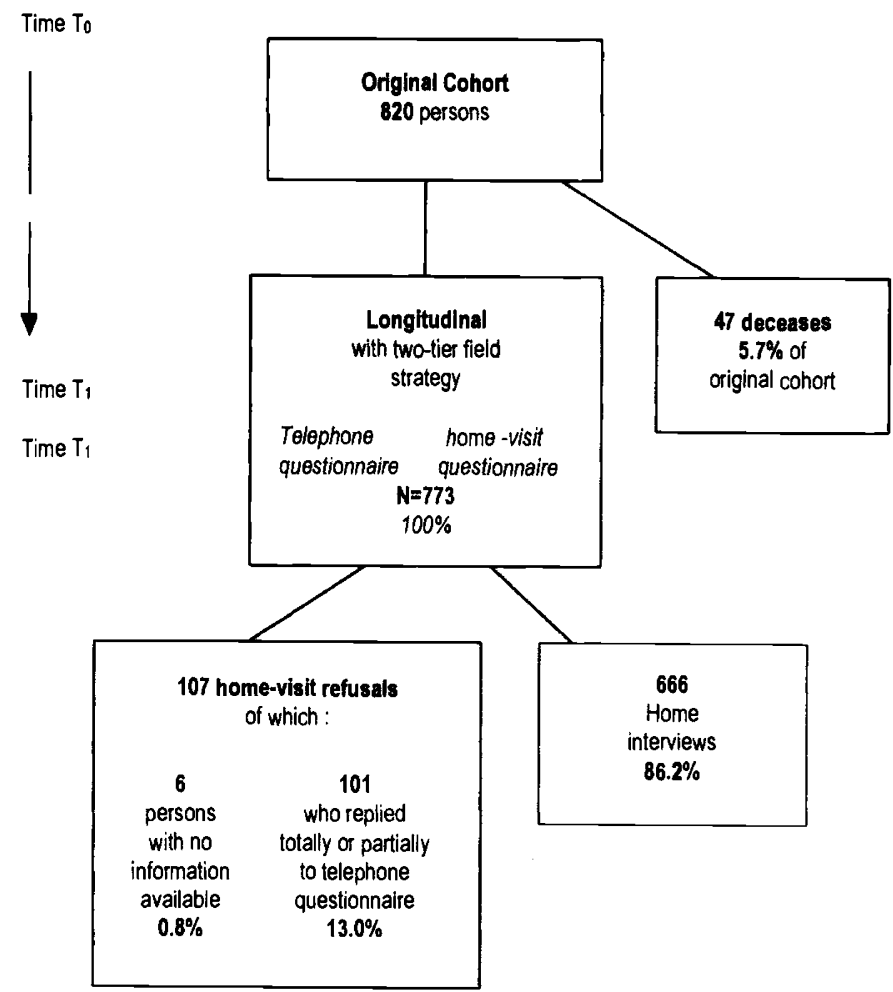


Over the ten-year period, one of the modes of exit from occupational life and transition to retirement was premature death, particularly for men, affecting $5.7 \%$ of the total population. Of the total number of survivors $(\mathrm{N}=773$ persons), only 6 , i.e. $0.8 \%$, were not retraced. The extremely low figure attests to the validity of the field strategy and to the representative nature of the population as studied 10 years on.

Of those in the new group, 13 (directly or through a representative) refused the home interview but did agree to answer some very brief questions over the telephone, some of which focused on current work conditions and the various modes of transition to retirement.

\section{Over the ten-year period: measurement of results and measurement of processes}

A longitudinal study presupposes the evolution of personal pathways within a fixed time-frame. In order to be able to describe changes properly at end of occupational life, it is essential in terms of the methodologies adopted to be able to distinguish between the measurement of results - in this particular instance the results at To (start time) and those at $\mathrm{T}_{1}$ (10 years later) - and the measurement of processes, i.e. what has occurred in the intervening period. These two types of measurement have already been discussed particularly in research work into the crisis in psychiatry (Gognalons-Nicolet, 1989). Processes must be studied according to two distinct time-frames:

- the impact over the period studied of certain situations obtained at start time ( $\mathrm{T} 0$ ): how these situations have developed up to $\mathrm{T} 1$;

- the causes of certain current situations (at $\mathrm{T}_{1}$ ): the current situation of the individuals concerned is a consequence of what occupational events?

The measurement of results is based on the algebraic differences among the percentages of different groups and need not necessarily refer to the same indivuduals in contradistinction, that is, to process scrutiny which focuses on the fate of the individuals themselves between $\mathrm{T}_{0}$ and $\mathrm{T}_{1}$.

Of the total original cohort $(\mathrm{N}=820)$ at $\mathrm{T} 0,4.3 \%(\mathrm{~N}=35)$ of the population had already entered retirement. For the purpose of examining changes over the 10 year period, we shall leave these retirees to one side.

At $\mathrm{T}_{1}, 45 \%(\mathrm{~N}=369)$ of the original cohort is still in active employment (part or full time), although 11 persons in this group admitted having interrupted occupational activity for some time before entering their current job. Of those 11 persons, 9 had been unemployed after being declared redundant and in two cases the enterprise had become bankrupt. $5.4 \%(\mathrm{~N}=44)$ of the original cohort are housewives without declared or remunerated occupational activity.

We have left these groups to one side so as to adhere strictly to the time-frame we set for our study.

\section{End of occupational life and the growth of unemployment}

The official or legal age for entitlement to an AVS pension, although it remains in Switzerland the basic yardstick for definition of retirement, is by no means the only yardstick since it signifies merely the drawing of the pension and may well not coincide with 
cessation of occupational activity, there being no legislation on the cumulation of a pension and income from work. Prior to the AVS pension age, three types of exit from occupational life need to be distinguished, each drawing upon its own set of independent institutional arrangements:

- situations related to current unemployment, which may or may not lead to definitive cessation of occupational activity;

- disability-insurance related situations;

- situations related to early or pre-retirement which we shall be examining in section 6 .

For each of these situations, according to the methodology devised previously, we shall be analysing the measurement of both results and processes.

Unemployment risk is covered by a two-tier public arrangement - a federal facility which provides an indemnity of $80 \%$ of the last salary (within a ceiling and for a defined duration) and a cantonal facility which, after a certain time, provides one-off supplementary indemnities. Once the legal period of insurance has elapsed, all benefits awarded are chargeable to "social aid". Using official data, we shall be focusing on those drawing unemployment benefits from public facilities. We find that the situation of some women those who were in active employment at $T_{0}$ and who, by $T_{1}$, had become housewives - falls outside the existing legal framework.

In terms of the processes involved, a distinction must be drawn between what has become of those who were unemployed at $T_{0}$ and the processes whereby those unemployed at $\mathrm{T}_{1}$ became so. At $\mathrm{T}_{0}$ very few persons $(\mathrm{N}=6)$ were actually unemployed and their occupational pathways reveal the traditonal inter-relations of gender, migration and health. Three men had migratory pathways, two of them with health problems. Three women had obtained a 1st Pillar pension and had their occupational lives complicated by family difficulties. Unemployment was limited but, where it did occur, was closely related to personal situations.

Ten years later, the situation had changed. For two age groups - currently aged between 50 and 60 years - Figure 3 indicates the proportion (between 4 and $8 \%$ ) of those affected by unemployment, with an implied question mark about hidden unemployment in the case of women who were actively occupied at $T_{0}$ and who had become housewives in the interval. The situation, recent in comparison with other European countries, places Switzerland in a more favourable position since it should be able to draw useful lessons from policies already actively pursued in other countries.

Figure 3: The situation 10 years on - occupational activity or unemployment?

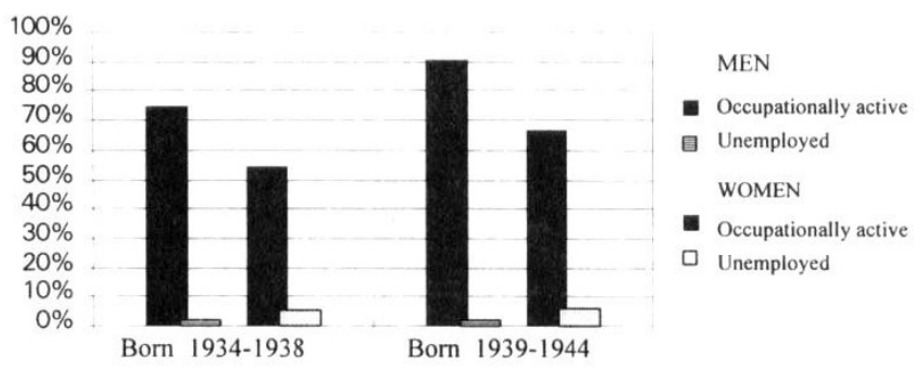


It should be noted that the number of women offically registered as unemployed is at least twice that of men. The reasons adduced by both genders are the same and have to do with internal and external restructuring of the profession and labour market. On the other hand, in addition to occupational traits which are identifiably masculine, gender differences highlight the distinguising characteristic of female careers where occupational and family activities become inextricably linked. Women, whatever their family or occupational status, whatever the nature of their career, are more affected by restructruring of enterprise and of their profession within the firm. Among men, professional staffs are also affected by restructuring. We shall return later to the problems of overstaffing in firms in need of restructuring policies.

Table 4: Qualitative study of the pathways of those unemployed at T1

Process study over ten years prior to current unemployment

\section{WOMEN \\ $N=16$}

\author{
Unemployment related \\ to former career, whether \\ continuing or intermuted \\ and to family status
}

7 continuing careers

(single, widowed, divorced)

6 interrupted careers

(all married)

1 lay off in catering on age groups

2 half-time refusals on health grounds leading to lay-off

All are members of general staff, skilled and unskilled

2 had professional jobs

for 6 months only

\section{MEN}

$N=7$
1 atypical career

(vicar tumed joumalist)

4 professional staff with inittal qualifications: apprenticeship, high occupational mobility, unemployment as a result of firm restructuring

1 self-employed, small enterprise mentality, order-book problems

1 already unemployed at $T_{0}$ (psychopathological problems) 
Older workers, especially female older workers, have been those primarily affected by the economic crisis and in particular by the restructuring of firms. Although sparse and with no claim to statistical validity, the above figures do appear to reveal a deterioration of end of occupational life, due to an increase in precarities like unemployment among the elder, similar to that encountered by Dessor and coll.(1991) in France. The latter authors have had the occasion to describe in detail how unemployment among older workers is aggravated by a kind of negative preselection with regard to the more vulnerable categories of employees - women, both skilled and unskilled, in all types of career, and men in atypical careers.

Alongside this "official" unemployment, there exists in equal proportion a kind of "hidden" unemployment among women - married women, that is, who, having not found jobs, have become housewives and ceased to apply for unemployment benefit. This situation, numerically almost as prevalent as that of women officially registered on unemployment benefit, is reminiscent of the inequalities, always exacerbated in times of economic crisis, between older men and women workers. The ambiguity of women's situations has to do rather with the legal procedures for the payment of unemployment benefit than with the role of the housewife traditionally viewed as "inactive" in offfical statistics. For the time being, we shall not examine the pathways of these occupationally active women become housewives.

\section{End of occupational life and growth of disability}

In similar fashion, disability insurance has in a number of countries become a route for early exit from occupational life for the older worker. Much the same could also be said of the extension in the duration of payment of sickness benefit (OECD, 1992). In Switzerland, the Law on Disability Insurance had remained confined to accidents and illness during occupational life with special emphasis on reinsertion into the world of work. As can be seen from the process study of those who were on DI at $\mathrm{T}_{0}(\mathrm{~N}=14)$, one quarter had deceased, one quarter were still drawing DI at $\mathrm{T}_{1}$ and only 2 of their number had resumed an occupational activity.

\section{Evolution of Disability Insurance between $T_{0}$ and $T_{1}$}

$(\mathrm{N}=14,100 \%)$

\section{3 deceased \\ 4 still on DI \\ 5 transferred to AVS \\ 2 resumed an occupation}

These initial figures confirm the severe pathology and restricted future open to this group with very little prospect of occupational reinsertion. Over the ten years, these figures have risen, given the operational definition (drawing of a full or partial pension) and also situations "on hold" where applications were made during or following absences due to a long illness. Table 5 (measurement of results) shows the increase in aggregate pensions for both men and women as well as applications in the pipe-line. 
Table 5: What became those on DI over the 10 years - measurement of results

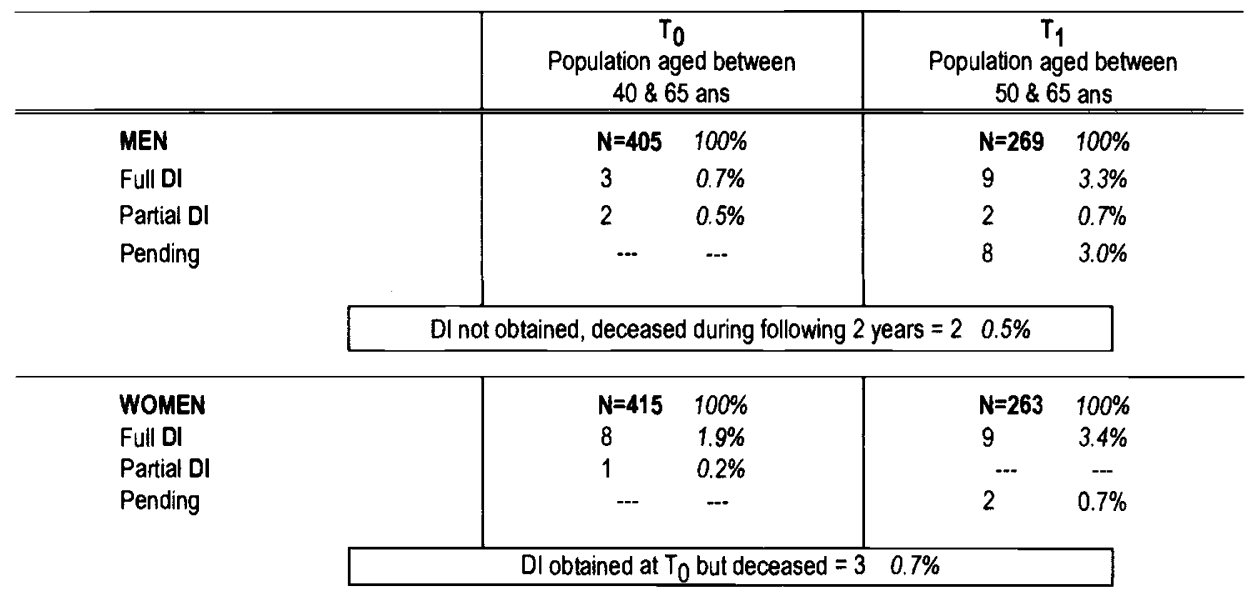

Table 6: displays the measurement of processes as defined above: on the one hand, the situations 10 years on of persons on DI at $\mathrm{T}_{0}$, and, on the other, situations at $\mathrm{T}_{0}$ of those currently on DI.

Table 6: Pathways of those involved with DI over 10 years - Process measurement

\begin{tabular}{|c|c|c|c|c|}
\hline & \multicolumn{2}{|c|}{ MEN } & \multicolumn{2}{|c|}{ WOMEN } \\
\hline & $\mathrm{N}=269$ & $100 \%$ & $\mathrm{~N}=263$ & $100 \%$ \\
\hline \multicolumn{5}{|l|}{$\mathrm{Dl}$ at $\mathrm{T}_{0}$} \\
\hline DI in 1985, with AVS in 1993 & 2 & $0.8 \%$ & 3 & $1.1 \%$ \\
\hline Dl in 1985, DI in 1993 & 2 & $0.8 \%$ & 2 & $0.8 \%$ \\
\hline DI in 1985,occupationally active in 1993 & 1 & $0.4 \%$ & 1 & $0.4 \%$ \\
\hline \multicolumn{5}{|l|}{ Dl in $T_{1}$} \\
\hline $\begin{array}{l}\text { Occupationally active in } 1985 \cdot \mathrm{Dl} \text { in } 1993 \\
\text { Unemployment benefit at } \mathrm{T}_{0}, \mathrm{Dl} \text { at } \mathrm{T}_{1}\end{array}$ & 9 & $3.3 \%$ & $\begin{array}{l}6 \\
1\end{array}$ & $\begin{array}{l}2.3 \% \\
0.4 \%\end{array}$ \\
\hline $\begin{array}{l}\text { Occupationally active in } 1985-\mathrm{Dl} \text { pending } \\
\text { or on long sick leave at } T_{1}\end{array}$ & 8 & $3.0 \%$ & 2 & $0.8 \%$ \\
\hline
\end{tabular}


In contrast to occupational reinsertion which is the legally stated purpose of DI, only a tiny proportion of those involved were able to resume occupational activity. The evolution of DI over the 10 years is marked by an increase in the waiting period for a pension in the event of a long illness. Even if in all cases health problems - physical or mental - predominate, they are nonetheless related to occupational attrition often accompanied by mental fatigue, overloading and stress which have triggered serious physical pathologies. For most women, family problems need to be added to this list of occupational vulnerabilities.

The vast majority of those on DI, while awaiting a disability pension or unemployment benefit, mention the relationship between occupational troubles and health problems. These situations coincide with social selection of the more vulnerable elements, either because of gender or because of atypical career patterns, with women most likely to combine both these traits.

\section{Between end of occupational activity and retirement - early retirement (or pre-retirement)}

This kind of withdrawal from the firm has, in a number of different forms, gained enormous ground affecting 51 persons $\left(6.6 \%\right.$ of the total cohort retraced at $\left.\mathrm{T}_{1}\right)$, almost one quarter of all those who had left the labour market. Alongside early retirement, traditionally entered into before the legal AVS age for health reasons, new forms of this phenomenon have emerged, often called pre-retirement and encouraged by firms. In all cases, firms proposed - or in a small number of cases, imposed - more or less favourable terms depending on length of career, the accumulated financial capital and on certain "bridge" arrangements providing access to 1st Pillar entitlements. The public sector - whether cantonal or municipal - proved highly innovative in its proposals on age and conditions for eligibility (bonuses, incentives and the bridge to AVS). The private, and above all the international sector, downsized its force of older workers by imposing special conditions. For some firms, it proved impossible to obtain precise details of their social plans for early retirement. Nevertheless, the majority of these situations had to do with internal restructuring in the context of age management within the enterprise.

51 persons withdrew into early retirement: for 45 of them, our information is complete: 8 were forced to quit and 37 agreed to quit.

For 6 of them, no additional information was available.

This kind of early exit from occupational life is tending to gain ground, as can be seen from Figure 7 which covers persons currently over 65 years and compares the two age groups currently over the AVS age. It should be remembered that these longitudinal data describe the process of transition to retirement of the same persons. Figure 7 suggests that early retirement is on the increase by comparison, that is, with retirement at the legal AVS age, and this is particularly the case with the female population. 
Figure 7: The situation 10 years on - occupational activity or early retirement

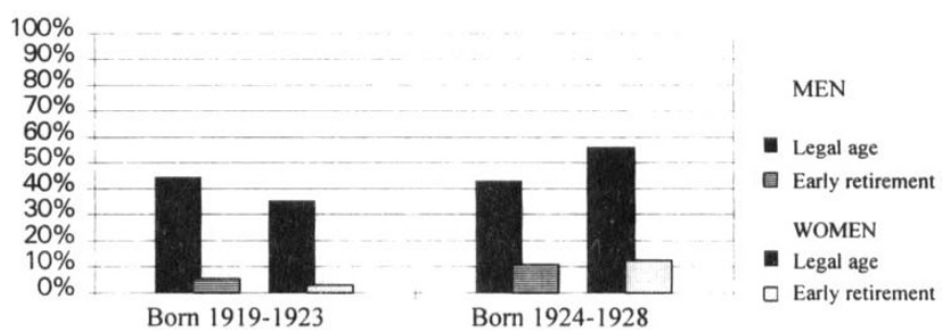

Save for the 6 persons who declined to discuss the details of their early retirement contracts over the 'phone, the vast majority of men $(78.3 \%)$, as also of women $(86.3 \%)$, stated that they had chosen this early exit from occupational life and that they were satisfied with the terms offered them. As a detailed examination will show later, this model reveals certain specific occupational and economic traits. As far as imposed early retirement is concerned, the range of pathways is displayed in the following qualitative study.

Table 8: Qualitative (by pathway) study of imposed early retirement $N=8$

\section{$\mathrm{N}=8$}

\section{TRADITIONAL}

Early retirement of healh grounds
$\begin{aligned} & \text { Male pathway } \\ & \begin{array}{l}\text { Female pathway } \\ \text { own health } \\ \text { husband's health }\end{array}\end{aligned}$
2
2
1

INNOVATIVE

Early retirement, redundancy with high severance pay for multinational professional staff Male pathway

Self-employed with a professional branch restructuring problem Male pathway

5 persons exited to early retirement on health grounds; on the other hand, for 3 persons, the imposed early retirement package was little short of a straight lay-off, with, depending upon the sector, financial compensation. This latter kind of early retirement arrangement, where financing is not from the pension fund, is close to those described by Gaullier (1993). The main difference is to be found in the accompanying institutional arrangements. 
In Switzerland, this sort of arrangement depends entirely on enterprise contracts or on the agreements which the firm has concluded with its pension fund.

\section{Retirement at the legal age or deferred}

191 persons (i.e. $23.3 \%$ of the original cohort) had reached, or were over, the AVS pension age when they began to draw a pension derived from their occupational activity. Of this group, 41 persons extended their occupational activity part- or full-time (see Figure 1).

It is above all men who extend their occupational activity beyond the age of 65 years, more or less equally divided between part- and full-time (see Table 9).

Table 9: Cessation or extension of occupational activity by AVS pensioners

\begin{tabular}{|c|c|c|c|}
\hline \multirow[t]{2}{*}{ Age at $T_{1}$} & \multirow[t]{2}{*}{$\begin{array}{l}\text { AVS pensioners } \\
\text { total cessation of } \\
\text { occupational activity }\end{array}$} & \multicolumn{2}{|c|}{$\begin{array}{l}\text { AVS pensioners } \\
\text { extension of } \\
\text { occupational activity }\end{array}$} \\
\hline & & Part-time & Full-time \\
\hline $\begin{array}{l}\text { MEN } 65^{+} \\
N=83 \\
100 \%\end{array}$ & $\begin{array}{c}57 \\
68.7 \%\end{array}$ & $\begin{array}{c}14 \\
16.7 \%\end{array}$ & $\begin{array}{c}12 \\
14.5 \%\end{array}$ \\
\hline $\begin{array}{l}\text { WOMEN 62+ } \\
N=105 \\
100 \%\end{array}$ & $\begin{array}{c}90 \\
84.9 \%\end{array}$ & $\begin{array}{c}10 \\
9.4 \%\end{array}$ & $\begin{array}{c}5 \\
5.7 \%\end{array}$ \\
\hline
\end{tabular}

Nevertheless, the reasons adduced for the extension of occupational activity very much depend on identity, gender, and the nature of the former occupation. Men will continue an occupational activity often because of their fondness for a job, because of the privileged social status it confers or because of the structural problems to which self-employment gives rise. Women in this connection make frequent reference to family problems; one half of women extended occupational activity for the same reasons as their male peers while the other half were obliged to continue an occupational activity for reasons of economic security.

Such extension of occupational activity is indicative of both the opportunities and limitations of Swiss retirement institutions. The absence of legislation on the drawing of a pension as a replacement income in the event of interruption of an occupational activity encourages men and one half of women to combine economic resources. It is a choice open to men to make, but for women an economic constraint often dictated by family obligations and the structural shortcomings of benefit facilities, particularly for the selfemployed with divergent 2 nd Pillar status. These patterns will be confirmed by the various positions occupied on the social scale and by income.

\section{Occupational and economic determinants of early retirement, retirement at the "legal" age and deferred retirement}

Three structural factors determine these types of retirement and, in terms of declared monthly income, serve to underline the differences in status between the self-employed 


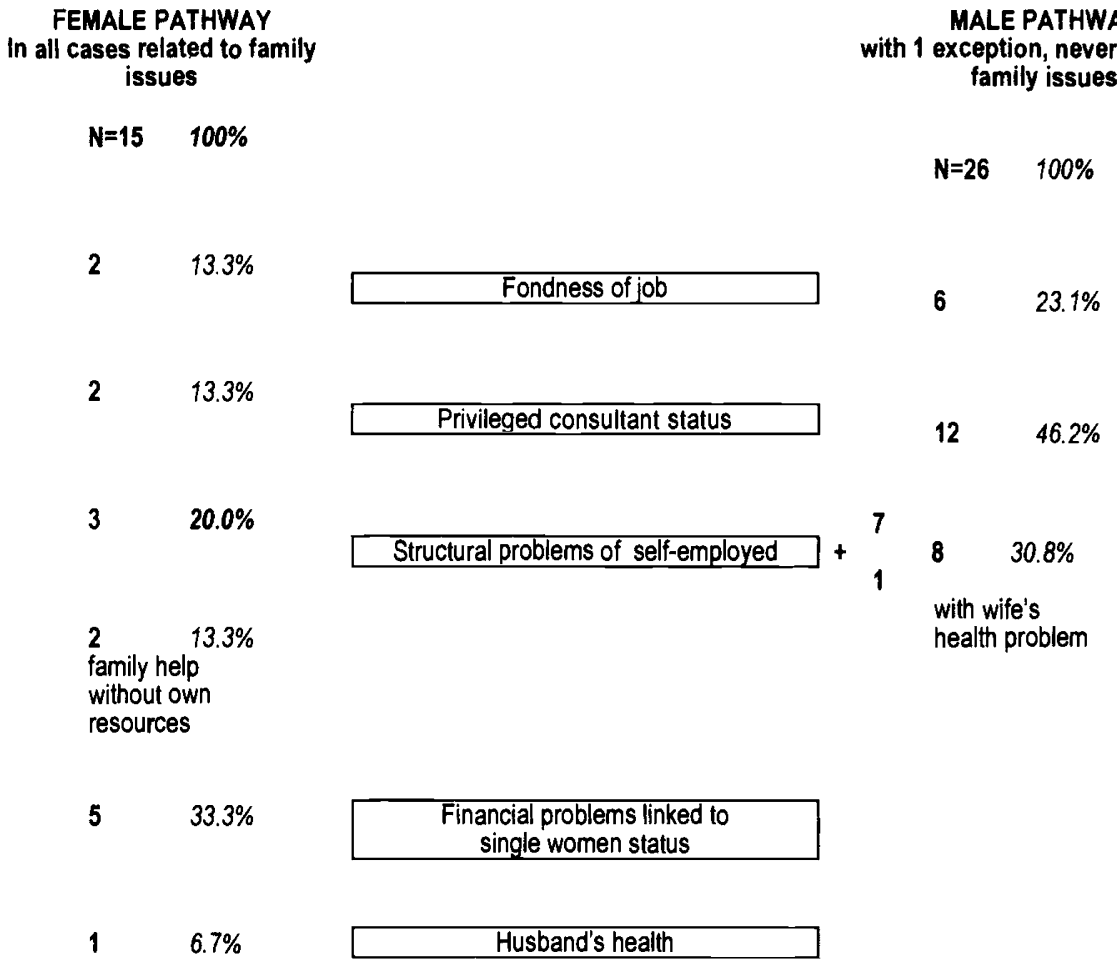

and the wage-earner, and between professional and non-professional employees. The fact of being self-employed or a wage-earner has implications for facilities under the 1st Pillar and, above all, under 2nd Pillar entreprise insurance schemes. Under the influence of a cohort effect (promotion by seniority universal among male employees - GognalonsNicolet, 1989), among men, almost as many of the over fifty years-olds hold professional posts $(\mathrm{N}=35)$ as non-professional ones $(\mathrm{N}=45)$. And yet, such promotion by seniority is true of male permanent careers only. Women hold vastly more non-professional jobs $(\mathrm{N}=100)$ than professional ones $(\mathrm{N}=14)$, a situation which results from career interruption and from inequalities and lack of opportunities on the labour market. We have had the occasion to develop and analyse these differences elsewhere (Bardet Blochet $\&$ al., 1987). Even though it enjoys a position of privilege, economic rationale remains a fairly reliable indicator of end-of-career differentials between the genders.

As Table 11 (for men) and Table 12 (for women) show, patterns of cessation and extension of occupational activity tend very much to depend on the position on the social scale. 
Table 11: Last socio-occupational position and retirement patterns - Men

\begin{tabular}{llll}
\hline & $\begin{array}{l}\text { Self-employed } \\
\mathrm{N}=\mathbf{2 8 - 1 0 0 \%}\end{array}$ & $\begin{array}{l}\text { Professional } \\
\text { wage-earners } \\
\mathrm{N}=\mathbf{3 9 - 1 0 0 \%}\end{array}$ & $\begin{array}{l}\text { Non-professional } \\
\text { wage-earners } \\
\mathbf{N}=\mathbf{4 5}-\mathbf{1 0 0 \%}\end{array}$ \\
\hline Retirement at legal age & 21.4 & 59.0 & 64.4 \\
Retirement deferred & 60.7 & 17.9 & 4.4 \\
Early Retirement & 17.9 & 23.1 & 31.1 \\
\hline
\end{tabular}

Men extend occupational activity for structural reasons, especially the self-employed $(60.7 \%)$ given the legal framework of the 2 nd Pillar and for professional employees the option remains an open one. Non-professional staff, on the other hand, opt more often than not for early retirement. Women, however, in non-professional jobs (100 out of 129 persons, or $77.5 \%$ of the total group) most frequently quit at the legal age or early, while one half of the self-employed continue their activity beyond the AVS age.

Table 12: Last socio-occupational position and retirement patterns - Women

\begin{tabular}{llll}
\hline & $\begin{array}{l}\text { Self-employed } \\
\mathrm{N}=15-100 \%\end{array}$ & $\begin{array}{l}\text { Professional } \\
\text { wage-earners } \\
\mathrm{N}=14-100 \%\end{array}$ & $\begin{array}{l}\text { Non-professional } \\
\text { wage-earners } \\
\mathrm{N}=100-100 \%\end{array}$ \\
\hline Retirement at legal age & 53.3 & 85.7 & 71.0 \\
Retirement deferred & 46.7 & $(7.1)$ & 7.0 \\
Early retirement & -- & $(7.1)$ & 22.0 \\
\hline & $\mathrm{X}^{2}=23.55 \mathrm{p}<.001$
\end{tabular}

Table 13: Monthly income by gender, household occupancy and different retirement routes

\begin{tabular}{|c|c|c|c|c|c|c|}
\hline & \multicolumn{3}{|c|}{ MEN } & \multicolumn{3}{|c|}{ WOMEN } \\
\hline & $\mathbf{N}$ & $\mu$ & e-type & $\mathbf{N}$ & $\boldsymbol{\mu}$ & é-type \\
\hline \multicolumn{7}{|l|}{ Retirement at legal age } \\
\hline - Couple & 33 & 5.737 & 1.45 & 30 & 5.266 & 1.52 \\
\hline - Single person & 9 & 4.111 & 2.20 & 44 & 3.545 & .92 \\
\hline \multicolumn{7}{|l|}{ Early retirement } \\
\hline - Couple & 19 & 5.684 & 1.49 & 12 & 5.916 & 1.08 \\
\hline - Single person & (2) & -- & -- & 9 & 5.111 & .60 \\
\hline \multicolumn{7}{|l|}{ Retirement deferred } \\
\hline - Couple & 15 & 7.200 & 1.60 & 6 & 5.166 & 2.08 \\
\hline - Single person & 3 & 5.333 & 2.08 & 5 & 4.000 & 1.41 \\
\hline
\end{tabular}


These socio-occupational determinants are confirmed by monthly incomes, broken down according to the number of persons in the household - a person living alone or a couple living alone - the two main types of family make-up in this age group. Deferred retirement, or extension of occupational activity, remains an option for men, and is related to income and status; it is an option chosen more by women on financial grounds if the person lives alone; with couples it is above all related to an individual's status as selfemployed. Single women, who are numerically important, enjoy the lowest resources whether they cease occupational activity at the legal age $(\mathrm{N}=44)$, through early retirement $(\mathrm{N}=9)$, or through deferred retirement $(\mathrm{N}=5)$.

\section{Management of exit from occupational life and of retirement: special characteristics of Swiss facilities}

Since the early 50's, the economic crisis has altered the end of occupational life and has called into question the relationship between retirement and social policy. While most other industrialised countries have integrated social criteria into their insurance systems (disability, unemployment and early retirement), Switzerland, where the impact of the crisis has been more recent and probably less serious (at least for the time being), has continued with compartmentalisation of its insurance.

Long-term unemployment among older workers, both men and women, has caused a number of countries to alter the rules for unemployment benefit and to guarantee resources or replacement resources until retirement according to age criteria. Financed either from unemployment funds or from pension funds, these replacement incomes have failed to distinguish between the older long-term unemployed and the early retiree, often confounding the two. In Switzerland, federal rules on long-term unemployment (even where they are made more flexible by cantonal regulations which have frequently encouraged definitive exit from the labour market) are still affected by the bias away from unemployment benefit towards cantonal social assistance. The unemployed, men and women, when their benefit entitlement runs out, thus become dependent on public assistance with all the institutional complications and adverse consequences for identity that this entails. As indeed has been attempted in other countries, active policies to contain this type of unemployment could be devised through, in particular, the use of qualification and reinsertion programmes.

Over this period, growth in all countries in the number of disability beneficiaries which has achieved the proportion of an explosion in Holland and Germany - has led to a relaxing of the rules with gradual introduction of social criteria in addition to medical ones. In Switzerland also this growth has been considerable and those concerned relate their occupational difficulties to physical and mental health problems. The integration of social criteria has not affected these facilities for they remain organised strictly according to medical criteria. Refusals by funds are, as a result, constantly increasing, the monitoring of elegibility criteria increasingly stringent and the problems of reinsertion growing in number. Institutional rigidity in the operation of the DI facility has even meant that some have been told "no disability benefit on economic grounds". In the end, this results in the deterioration of certain situations where health problems are compounded by occupational, economic and identity difficulties. 
With social situations of this kind on the increase, Swiss insurance systems remain compartmentalised, each prey to the problem of finding resources. One needs to have experience of the debates specific to each of these various systems and of their internal rivalries to understand how difficult it is for them to follow the march of recent social events. What is to be done with an army of people who cannot find work and who have health problems? Who is going to foot the bill? Public assistance or one of the insurance schemes? What will be the impact of all of this on social welfare in the future and on social cohesion as a whole?

Early retirement, closely associated as it is with the condition of wage-earner and with the completion of a full career, makes it possible in many activity sectors to manage the end of career according to the needs of entreprise and, it appears, according to individual choice. In similar fashion, extension of occupational activity has enabled:

- in particular those women whose AVS resources are inadequate to continue working on economic grounds;

- self-employed men and those in privileged social categories to continue in a job they are fond of and whose status they cherish and not only to conserve their income but sometimes even to increase it.

Thus has a coherent pension system in Switzerland adapted to the vicissitudes of the economic crisis by combining the universality of the 1st Pillar with the specificity of the 2nd, enabling both entreprise and the individuals concerned to shape to their satistaction end-of-career and transition to flexible and diversified retirement. The architecture and cogency of the system, however, reposes on the above-all masculine model of the full occupational career. Those, both men and women, who, for personal or situational reasons, have not managed, or will not manage, to fulfil this condition (women in the home, parttimers whose work is not subject to 2nd Pillar contribution, and the long-term unemployed) will, during their years of late-middle and old age, remain dependent on public assistance. Women, in particular, are overlooked because they have either no careers or careers that are incomplete. The recent study of the position of women in AVS (Luchsinger, 1995) lays great stress on the changes proper to women's careers.

With the problems of overstaffing in firms and the mounting tide of unemployment, we shall be witnessing the marginalisation of growing numbers of young job-seekers and of older workers. The increase in part-time patterns and in insecure jobs of every conceivable kind for those groups that are especially vulnerable require a broad-fronted approach which must necessarily embrace employment, social welfare and retirment. How, then, in light of the new questions we face about unemployment and job security, can we best rethink Switzerland's system of social welfare and make the best possible use of the experience and achievements of other European countries? 


\section{REFERENCES}

BARDET-BLOCHET, A., GILLIOZ, L., GEORG, D., GOGNALONS-NICOLET, M., Les femmes 46. cadres en Suisse: un défi à l'égalité professionnelle, Revue Suisse de Sociologie, 1, (1987), pp. 29-

DESSOR D., SCHRAM, J., VOLKOFF, S., Du "handicap de situation" à la sélection-exclusion: une étude des conditions antérieures aux licenciements économiques, Travail et emploi, $\mathrm{XII}^{\mathrm{e}}$ année, 48, (1991), pp. 31-47.

DRURY, E., Discrimination fondée sur l'âge exercée contre les travailleurs âgés de la Communauté européenne. Une analyse comparative. Eurolink Age, Londres, (1993).

EME, B., LAVILLE J.-L., (dir.), Cohésion sociale et emploi, Paris, Desclé de Brouwer, (1994).

GAULLIER, X., GOLDBERG; A., Travailleurs âgés: Conditions de travail et transition vers la retraite. Genève, BIT, Service des conditions de travail et des activités de bien-être, (1993).

GAULLIER, X., La décennie de la retraite,Gérontologie et Société, 70, (1994), pp. 95-118.

GOGNALONS-NICOLET, M., La Maturescence, 40-65 ans âges critiques?, Lausanne, P.M. Favre, (1989).

GOGNALONS-NICOLET, M., ANDREOLI, A., Evaluer la crise?, L'information psychiatrique, 65, 9, (1989), pp. 891-900.

GOGNALONS-NICOLET, M., BARDET-BLOCHET, A., PILETTA-ZANIN, S., SPILLMANN, A., Situations à risque de maladies graves entre 40 et 65 ans: perspectives prédictives. Rapport F.N.R.S., (1991).

GOGNALONS-NICOLET, M., BARDET-BLOCHET, A., PILETTA-ZANIN, S., La maturescence: santé et maladie entre 40 et 65 ans. In Walter Weiss, Ed. La Santé en Suisse. Office Fédéral de la Statistique, Lausanne, Payot, (1993), pp. 143-153.

GOGNALONS-NICOLET, M., Inégalités sociales et mortalité d'une population adulte. Document ronéo, (à paraître 1996).

GREBER, P.-Y., Les pensions en Suisse ; architecture, régime de base public, régimes professionnels, Cahiers genevois et romands de sécurité sociale, 12, (1994), pp. 59-99.

HÖPFLIGER, F., STUCKELBERGER, A., Vieillesse et recherche sur la vieillesse en Suisse, Réalités Sociales, Lausanne, (1992).

LALIVE d'EPINAY, C., BOLZMAN, C., MAHEEN, S., Retirement in Switzerland in : K.S. Markides \& COOPER, C.L., Ed, Retirement in Industrialized Societies, John Wiley \& Sons, (1987), pp. 103-129.

LUCHSINGER, C., Solidarität - Selbständingkeit. Der schwierige weg zu einer Gleichberechtigung der Geschlechter in der AHV, 1939-1980. Zürich, Chronos Verlag, (1995).

OCDE Statistiques de la population active 1970-1990.

Rapport du Département fédéral de l'intérieur sur les trois piliers (1995), Berne, OFAS.

SOMMER, J., HÖPFLINGER, F., Changements des modes de vie et avenir de la sécurité sociale en Suisse, Réalités Sociales, Lausanne, (1990).

Vieillir en Suisse (1979), Rapport, Office Fédéral des imprimés et du matériel, Berne.

Vieillir en Suisse (1995), Bilan et Perspectives, Rapport de la Commission fédérale, Berne. 